\title{
Photosynthetic activity of macroalgae along a bathymetric gradient: interspecific and seasonal variability
}

\author{
Natàlia Sant, Enric Ballesteros \\ Centre d'Estudis Avançats de Blanes, CSIC, Acc. Cala Sant Francesc 14, 17300 Blanes, Girona, Spain. \\ (NS): E-mail: natsfunk@gmail.com. ORCID iD: http://orcid.org/0000-0002-5660-0131 \\ (EB) (Corresponding author) E-mail: kike@ ceab.csic.es. ORCID iD: http://orcid.org/0000-0001-5532-5337
}

\begin{abstract}
Summary: Marine macroalgae are unevenly distributed with depth, with substitutions of the dominant species along the bathymetric gradient. Since light shows a sharp decrease with depth and is a critical factor for algal growth, we hypothesize that species dominating at a certain depth are the best adapted to the light environment reaching that depth. To this end, we selected seven species of Mediterranean macroalgae distributed from 0 to $50 \mathrm{~m}$ depth and looked for their photosynthetic performances. Photosynthetic responses showed striking differences, with photosynthetic efficiencies increasing at increasing depths. However, neither oxygen production at high light levels nor respiration are related to depth but seem to respond to other factors such as thallus thickness or nutrient availability. Some species show high production values in agreement with their high productivity and fast growth, while others show low production values but high biomass and durability. Thus, the species that dominates at each light level seems to be the one that makes best use of the light environment to accomplish its life cycle.
\end{abstract}

Keywords: macroalgae; photosynthesis; depth gradients; efficiency; light.

Actividad fotosintética de macroalgas a lo largo de un gradiente batimétrico: variabilidad interespecífica y estacional

Resumen: Las macroalgas marinas se distribuyen de forma desigual en profundidad, observándose una substitución de las especies dominantes a lo largo del eje batimétrico. Como la luz muestra una disminución muy marcada con la profundidad y es un factor crítico para el crecimiento de las algas, nuestra hipótesis es que aquellas especies que dominan a una cierta profundidad son las que están mejor adaptadas al ambiente lumínico de esa profundidad. Para comprobarlo hemos seleccionado siete especies de algas marinas mediterráneas distribuidas entre 0 y $50 \mathrm{~m}$ de profundidad y hemos calculado sus parámetros fotosintéticos. Las respuestas fotosintéticas muestran grandes diferencias entre especies, con las eficiencias fotosintéticas que aumentan al aumentar la profundidad donde crecen las algas. Sin embargo, tanto la producción de oxígeno a elevados niveles de luz como la respiración no están relacionadas con la profundidad, y parecen determinadas por otros factores como el grosor del talo o la disponibilidad de nutrientes. Algunas especies muestran valores de producción elevados, en sintonía con su alta productividad y rápido crecimiento, mientras que otras muestran bajos valores de producción pero una elevada biomasa y perdurabilidad. Así pues, las especies que dominan en cada ambiente lumínico parecen ser aquellas que utilizan de mejor manera la luz disponible donde crecen para completar con éxito su ciclo de vida.

Palabras clave: macroalgas; fotosíntesis; gradientes de profundidad; eficiencia; luz.

Citation/Como citar este artículo: Sant N., Ballesteros E. 2020. Photosynthetic activity of macroalgae along a bathymetric gradient: interspecific and seasonal variability. Sci. Mar. 84(1): 7-16. https://doi.org/10.3989/scimar.04995.06A

Editor: E. Cebrián.

Received: September 12, 2019. Accepted: January 21, 2020. Published: February 14, 2020.

Copyright: $\odot 2020$ CSIC. This is an open-access article distributed under the terms of the Creative Commons Attribution 4.0 International (CC BY 4.0) License.

\section{INTRODUCTION}

Bathymetric distribution of aquatic macrophytes depends on several environmental factors, including the type, slope and orientation of the substrate, light intensity, hydrodynamism, nutrient availability and grazing pressure. Among these factors, light levels and hydrodynamism show a sharp decrease with depth (Ballesteros and Zabala 1993). Light is also a resource that is critical for algal growth and it is the main limiting factor for deep-water algal development in places where appropriate substrate is available (Spence 1976, Denni- 
son 1987, Lobban and Harrison 1994). The maximum depth of most aquatic macrophytes in a specific location is inversely related to the capacity of water to absorb the photosynthetic active radiation (Kirk 1994), i.e. the clearer the water is, the deeper the algae can grow. However, the maximum depth where a macrophyte can grow also depends greatly on its physiological features. Some macrophytes (photophilic) are always found in shallow waters, where they are subjected to strong light levels, while others (sciaphilic) mainly grow in deep waters or in places with low light levels.

As a result, different species of aquatic macrophytes usually dominate at different depth intervals, a feature that is known as vertical zonation (Dring 1986, Kirk 1994). The presence/absence of a macrophyte at a certain depth depends on the equilibrium between its physiological ability to grow (which in turn depends on the available light, temperature, nutrient availability and other factors) and the ecological processes that imply biomass loss (including unsuitable environmental conditions and herbivory), together with the ability to outcompete with or tolerate other species (Airoldi 2000). In this context, we hypothesize that dominant species at a certain depth are those that outcompete others, whether because they can grow faster or because they are persistent in occupying space. Since light is a pivotal environmental factor for macrophyte growth and it decreases with depth, we expect macrophytes that dominate at different depths to show different photosynthetic performances related to light availability.

In order to provide species distribution models, it is necessary to know the physiological responses of organisms to changing environments. In terrestrial ecology one of the most accepted findings is the existence of differences in the photosynthetic performance of "sun plants" versus "shade plants" (Boardman 1977, Field 1988, Boston et al. 1989): plants living in high light environments should display a low photosynthetic efficiency at low light levels but a high photosynthetic capacity at high light levels, while those living at low light environments should display a high photosynthetic efficiency at low light levels and low photosynthetic capacity at high light levels. In benthic ecology, even if this model has been tested experimentally (Herbert and Waaland 1988, Delgado et al. 1995, Beach and Smith 1996), some studies demonstrate that the photosynthetic capacity is mainly related to thallus morphology and thickness (Arnold and Murray 1980, Littler 1980, Lüning and Dring 1985) or to the growth strategy of each species (King and Schramm 1976, Peckol and Ramus 1988).

Here we aim to test whether there is a relationship between the bathymetric distribution of several Mediterranean erect macroalgae and their photosynthetic performances. If the relationship exists, a response typical of "sun plants" would be expected in photophilic algae, while a response typical of "shade plants" would be expected in sciaphilic algae. To this end, we selected seven species of Mediterranean macroalgae that predominate at different depths, from 0 to $50 \mathrm{~m}$, and compared their seasonal photosynthetic performance at different light levels. We also measured carbon, nitrogen and phosphorus content in tissue samples as nutrients have been claimed as a limiting factor for photosynthesis and growth in Mediterranean macroalgae (Ballesteros 1992, Delgado et al. 1994).

\section{MATERIAL AND METHODS}

Samples were collected at Estell des Coll $\left(39^{\circ} 07^{\prime} 19^{\prime \prime} \mathrm{N} 2^{\circ} 56^{\prime} 09^{\prime \prime} \mathrm{E}\right)$, a small islet within the Archipelago of Cabrera National Park (Balearic Islands, western Mediterranean). The water column remains very clear even in winter, with photon flux density (PFD) extinction coefficients ranging from $0.053 \mathrm{~m}^{-1}$ in summer to $0.076 \mathrm{~m}^{-1}$ in winter (Ballesteros and $\mathrm{Za}$ bala 1993). Yearly average PFD ranges between $55 \%$ (at $0.2 \mathrm{~m}$ ) and $2 \%$ (at $50 \mathrm{~m}$ ) of the superficial PFD. Nutrient levels are always low, corresponding to oligotrophic to ultra-oligotrophic environments, with mean dissolved phosphate values ranging from 0.04 to 0.08 $\mu \mathrm{mol} \mathrm{l}^{-1}$ and nitrates ranging from 0.25 to $0.80 \mu \mathrm{mol}$ $1^{-1}$ (Ballesteros and Zabala 1993). Temperature ranges from $14^{\circ} \mathrm{C}$ to $15^{\circ} \mathrm{C}$ (January-March, all depths) to $27^{\circ} \mathrm{C}$ at surface (August-September) and $20^{\circ} \mathrm{C}$ to $21^{\circ} \mathrm{C}$ (October) at $50 \mathrm{~m}$ depth (Ballesteros and Zabala 1993).

The southern part of the Estell des Coll islet has an almost vertical wall that sinks down to $52 \mathrm{~m}$ depth, showing five different algal assemblages (Ballesteros et al. 1993, Sant et al. 2017) from the shallows to the bottom: the assemblages dominated by Carpodesmia amentacea v. stricta (0.2 m depth) (hereinafter Carpodesmia stricta), Padina pavonica and Dictyota fasciola (1-8 m depth), Carpodesmia brachycarpa v. balearica (10-16 m depth) (hereinafter Carpodesmia balearica), Dictyopteris polypodioides (18-40 $\mathrm{m}$ depth) and the coralligenous assemblage (42-52 $\mathrm{m}$ depth) dominated by calcareous encrusting algae (Ballesteros 2006), with Flabellia petiolata and Halopteris filicina as the main erect species at the sampling site. These seven erect algae were selected to measure their photosynthetic performance. The composition of the assemblages and their seasonality are thoroughly described in Sant et al. (2017).

Sampling was performed seasonally, in February (winter), May (spring), early September (summer) and early December (autumn). The abundance of the main species with depth was estimated by means of reticulated quadrats. Species abundance was estimated using $0.25 \times 0.25 \mathrm{~m}$ quadrats divided into 25 sub-quadrats of $5 \times 5 \mathrm{~cm}$. Four quadrats were positioned haphazardly at depths of $0.2,5,12,25$ and $50 \mathrm{~m}$ in every season, making a total of 16 quadrats per year and depth. Main macroalgae within each sub-quadrat were identified and the percentage of sub-quadrats in which a species appeared was recorded and used as a measure of occurrence. A highly abundant species that appeared in all 25 sub-quadrats would produce a presence of $100 \%$, whereas a total lack of a species would produce a presence of 0\% (Sala and Ballesteros 1997, Tomas et al. 2011, Teixidó et al. 2018). The final abundance of a species within each depth was then calculated as the mean of the percentage presence values of the quadrats sampled. 
In every season, specimens of the seven species were collected at their preferred depth using SCUBA diving. Diving was performed in late afternoon every day, and the algae were collected and maintained overnight, submerged at sea inside mesh bags and protected from direct light until the next morning. Specimens were sorted and prepared for photosynthesis and respiration assays in the early morning just before the experiments began. Material selection, manipulation and assays were performed according to the recommendations made by Littler (1979), Littler and Arnold (1980) and Littler and Littler (1985).

Photosynthesis assays were performed in $270 \mathrm{~mL}$ glass bottles. Whole blades or branches (in Carpodesmia spp.) were selected among the collected material, cleaned of epiphytes and introduced into $270 \mathrm{~mL}$ glass bottles containing seawater and a glass marble hanging inside the bottle and subjected with a nylon line. The bottles with the algal specimens were hung in a structure hanging from a buoy and placed in the sea at Cabrera harbour at $2 \mathrm{~m}$ depth. Waves moved the structure and the glass marbles shook the water inside the bottle, breaking diffusion gradients. Three replicates per species and three empty bottles (to account for variation not due to macroalgae) were assayed every day at a different PFD, making a total of 24 assays per day. Ten different PFDs were obtained by covering the structure with a different number of neutral filters, using a black filter to measure dark respiration. Ambient light in each assay was measured using a Li-1000 SPQA spherical sensor deployed at the same site and depth of the hanging structure. PFD attenuation inside the hanging structure with increasing number of filters was also measured $\left(\mathrm{y}=100 \mathrm{e}^{-0.52 \mathrm{x}}, \mathrm{R}^{2}=0.99, \mathrm{x}=\right.$ number of neutral filters, $y=\%$ ambient PFD). Light intensities ranged between 0 and $2000 \mu \mathrm{mol}$ photon $\mathrm{m}^{-2} \mathrm{~s}^{-1}$. Incubation times ranged between 3 and $4 \mathrm{~h}$ and assays were always performed between 10:00 am and 2:00 pm. Every specimen was used only once, which made each assay independent from the others. Oxygen was measured after the assay with an Orbisphere 2607 oxygen analyser with an accuracy of $0.01 \mathrm{mg} \mathrm{O}_{2} \mathrm{1}^{-1}$. Oxygen production/dark consumption was measured as the difference between the oxygen from each bottle containing a specimen and the average of the three empty bottles. Specimens used in the assays were dried at $60^{\circ} \mathrm{C}$ for 48 hours to obtain their dry weight (Boudouresque 1971, Romero 1981, Ballesteros 1986). The specimens were then burned in an oven for $4 \mathrm{~h}$ at $500^{\circ} \mathrm{C}$ to obtain the ash free dry weight (AFDW) (Brinkhuis 1985).

The data obtained in the assays was pooled together for every species to obtain the photosynthesis/light intensity (PFD) curves. We did not adjust any function to the curves due to the existence of different models (see Jones et al. 2014 for a discussion). Alternatively, we obtained the photosynthetic parameters directly based on photosynthesis at saturation levels $\left(\mathrm{P}_{\max }\right)$ and variation of photosynthesis at low light levels (photosynthetic efficiency, $\alpha$ ) (Arenas et al. 1995, Gómez et al. 1996, Gómez and Wiencke 1997), which allows comparisons within our data. The photosynthetic parameters finally obtained were (Fig. 1) dark respiration $\left(\mathrm{R}_{\mathrm{d}}\right.$ in $\mathrm{mg} \mathrm{\textrm {O } _ { 2 }}$

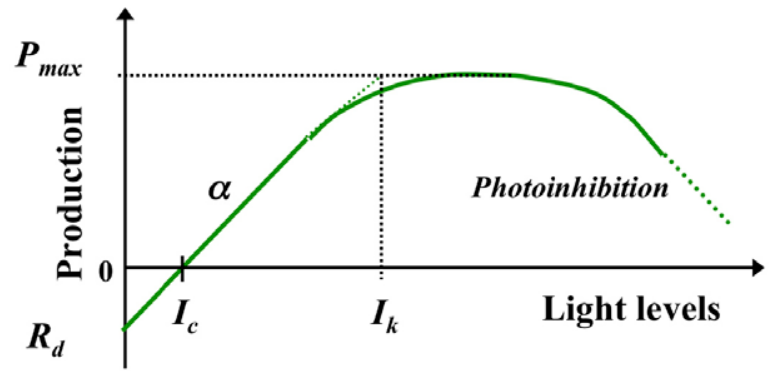

Fig. 1. - Theoretical representation of a photosynthesis/irradiance curve and the corresponding photosynthetic parameters: photosynthesis at saturation $\left(\mathrm{P}_{\max }\right)$, light at saturation $\left(\mathrm{I}_{\mathrm{k}}\right)$, light at compensation $\left(I_{c}\right)$, photosynthetic efficiency $(\alpha)$ and dark respiration $\left(R_{d}\right)$.

gAFDW $\left.^{-1} \mathrm{~h}^{-1}\right)$, light compensation point $\left(\mathrm{I}_{\mathrm{c}}\right.$ in $\mu \mathrm{mol}$ photon $\mathrm{m}^{-2} \mathrm{~s}^{-1}$, photosynthetic efficiency $\left[\alpha\right.$ in $\mathrm{mg} \mathrm{O}_{2}$ $\mathrm{m}^{2} \mathrm{~s}$ (umol photon gAFDW $\left.\mathrm{h}\right)^{-1}$ ], light at saturation levels $\left(\mathrm{I}_{\mathrm{k}}\right.$ in $\mu \mathrm{mol}$ photon $\mathrm{m}^{-2} \mathrm{~s}^{-1}$ ), and photosynthesis at saturation levels $\left(\mathrm{P}_{\max }\right.$ in $\mathrm{mg} \mathrm{O}_{2} \mathrm{gAFDW}^{-1} \mathrm{~h}^{-1}$ ).

Nutrient content in tissues for each species was measured seasonally from specimens collected at the same depths as the specimens used for the photosynthetic assays. The samples were frozen after collection and, on arrival in the laboratory, they were defrosted, dried and triturated. Carbon and nitrogen were measured with a Carlo-Erba Autoanalyzer (Serveis Científico-Tècnics, University of Barcelona) and phosphorus was analysed with an inductively coupled plasma mass spectrometer (ICP) after acid digestion of the samples, following Mateo and Sabaté (1993).

Differences between $\mathrm{P}_{\max }$ and $\mathrm{R}_{\mathrm{d}}$ between species and between seasons were tested with a two-way ANOVA followed by a Tukey test. $P$. pavonica and $D$. fasciola were not included because they were highly seasonal. The data were log-transformed in order to accomplish the assumptions of ANOVA. Relationships between parameters were estimated using Pearson linear correlations. A principal component analysis (PCA) (ter Braak 1990) was performed using all the photosynthetic parameters obtained seasonally $\left(\mathrm{P}_{\max }\right.$, $\left.\mathrm{R}_{\mathrm{d}}, \mathrm{I}_{\mathrm{c}}, \mathrm{I}_{\mathrm{k}}, \alpha\right)$.

\section{RESULTS}

Distribution of the selected species with depth is presented in Figure 2. The abundances of the species followed a bathymetric pattern, as expected, with every species dominant in a particular assemblage.

Curves relating photosynthesis and light levels differed between species and sometimes between seasons (Fig. 3). Dictyopteris polypodioides showed the highest $\mathrm{P}_{\max }$ and $F$. petiolata the lowest (Table 1, Fig. 4A). Specific differences in $\mathrm{P}_{\max }$ for the five species that are present all year round were very significant (Table 2). However, C. balearica was the only species whose $\mathrm{P}_{\max }$ did not differ from the others (Tukey test). Seasonal differences were also very significant globally (Table 2), with the lowest values attained in winter for deep-water species. Seasonality seemed to be much lower in deep-water species than in perennial shallow water ones, while non-perennial species (D. fasciola, 


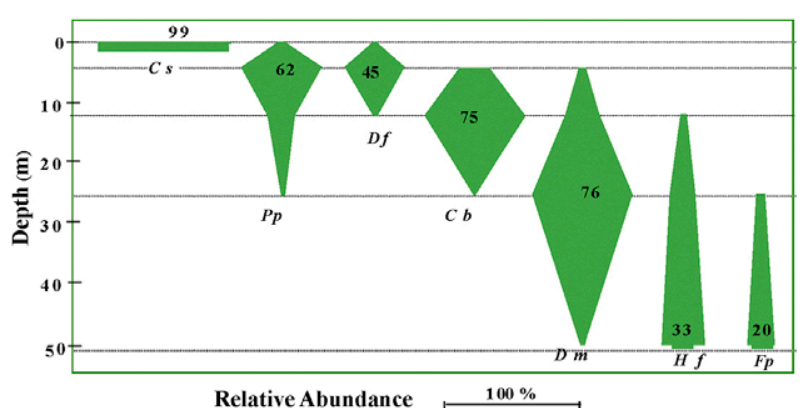

Fig. 2. - Bathymetric distribution of the main erect algal species dominating the assemblages at Estell des Coll (Cabrera, Balearic Islands). Abundance values correspond to the annual average estimated from 16 reticulated quadrats (4 quadrats per depth and season). Numbers represent the abundance percentage at the depth of highest occurrence.
$P$. pavonica) showed a relatively high and constant $\mathrm{P}_{\max }$ (Table 2). Moreover, there was no relationship between $\mathrm{P}_{\max }$ and light levels attained at the depths and seasons where a species was dominant (Table 3 ).

Carpodesmia stricta showed the highest light at saturation levels $\left(\mathrm{I}_{\mathrm{k}}\right)$, followed by $C$. balearica (Table 4). Dictyotales (P. pavonica, D. fasciola and D. polypodioides) showed intermediate values and $H$. filicina and particularly $F$. petiolata showed the lowest ones (Fig. 4B). Species receiving more light showed the highest $I_{k}$ values (Table 3). There were no clear seasonal patterns (Table 4). Inhibition of photosynthesis at high light levels (photoinhibition) was not usual in our assays and when it happened it occurred at PFDs over $850 \mathrm{umol}$ photon $\cdot \mathrm{m}^{-2} \mathrm{~s}^{-1}$. This was the case of $C$. balearica $(\mathrm{p}<0.001)$ and D. polypodioides $(\mathrm{p}<0.05)$ in
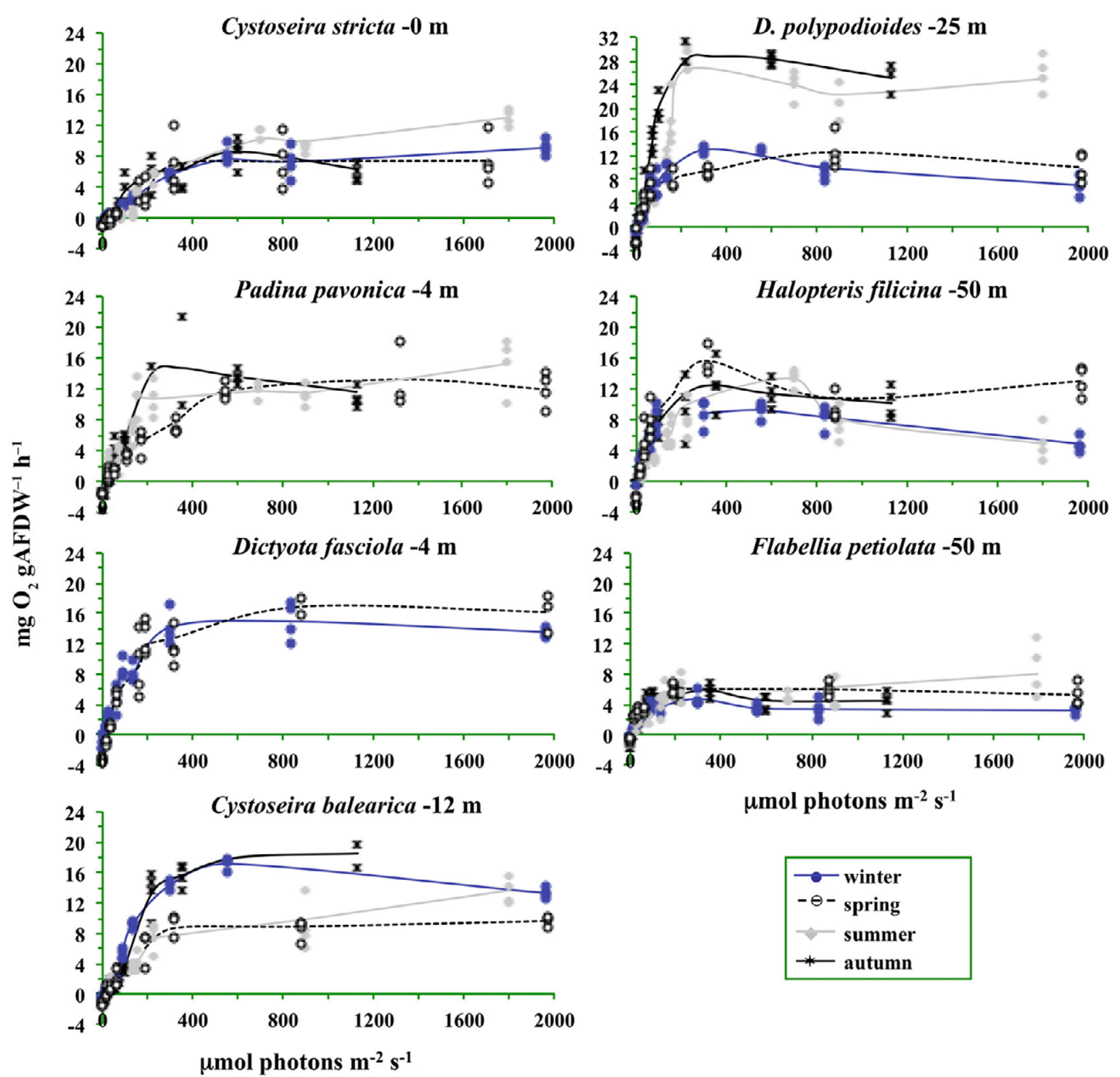

Fig. 3. - Photosynthesis/irradiance curves for the seven species in different seasons. Note that the Y scale for Dictyopteris polypodioides is different. 
Table 1. - Photosynthesis at saturation $\left(\mathrm{P}_{\max }\right.$, in $\left.\mathrm{mg} \mathrm{O}_{2} \mathrm{gAFDW}^{-1} \mathrm{~h}^{-1}\right)$ for species and season.

\begin{tabular}{|c|c|c|c|c|c|c|}
\hline $\mathrm{P}_{\max }$ & winter & spring & summer & autumn & mean & $\mathrm{sd}$ \\
\hline Carpodesmia stricta & 8.2 & 5.9 & 13.0 & 6.4 & 8.4 & 3.2 \\
\hline Dictyota fasciola & 14.2 & 13.9 & - & - & 14.1 & 0.2 \\
\hline Padina pavonica & - & 12.2 & 11.6 & 13.1 & 12.3 & 0.7 \\
\hline Carpodesmia balearica & 17.2 & 8.3 & 13.6 & 17.6 & 14.2 & 4.3 \\
\hline Dictyopteris polypodioides & 13.0 & 10.7 & 26.1 & 27.5 & 19.3 & 8.7 \\
\hline Flabellia petiolata & 3.7 & 5.7 & 6.0 & 4.9 & 5.1 & 1.0 \\
\hline Halopteris filicina & 8.6 & 14.1 & 13.3 & 10.9 & 11.7 & 2.5 \\
\hline
\end{tabular}
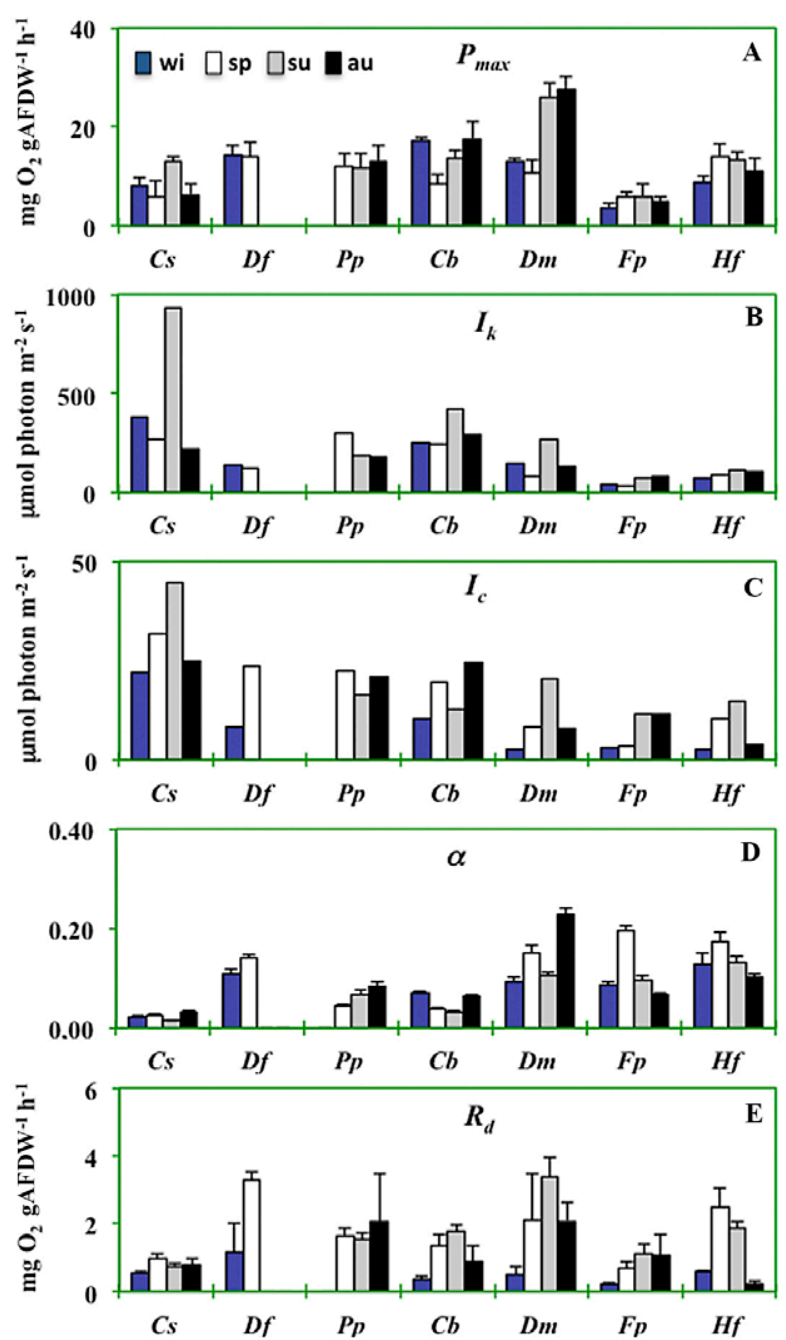

Fig. 4. - Seasonal values of the photosynthetic parameters: photosynthesis at saturation $\left(\mathrm{P}_{\mathrm{max}}\right)$, light at saturation $\left(\mathrm{I}_{\mathrm{k}}\right)$, light at compensation $\left(\mathrm{I}_{\mathrm{c}}\right)$, photosynthetic efficiency $(\alpha)$ and dark respiration $\left(\mathrm{R}_{\mathrm{d}}\right)$. Cs, Carpodesmia stricta; Df, Dictyota fasciola; Pp, Padina pavonica; $\mathrm{Cb}$, Carpodesmia balearica; Dp, Dictyopteris polypodioides; Fp, Flabellia petiolata; Hf, Halopteris filicina.

winter and also in $H$. filicina in winter $(\mathrm{p}<0.01)$ and summer $(\mathrm{p}<0.001)$.

Light at compensation was lower in deep-water species than in shallow-water species (Table 5). Compensation points were always lower in winter than in other seasons, while their highest values were present in summer and autumn (Fig. 4C). Regarding photosynthetic efficiency, deep-water species were the most efficient, with the highest values for $F$. petiolata and $H$. filicina in spring and for $D$. polypodioides in autumn (Table 6, Fig. 4D). Photosynthetic efficiency was very low for $C$. stricta all year round, while D. fasciola
Table 2. - Results of the two-way ANOVA for $\mathrm{P}_{\max }$ and $\mathrm{R}_{\mathrm{d}}$.

\begin{tabular}{llccccc}
\hline & factor & df & MS & $\%$ variance & $\mathrm{F}$ & $\mathrm{p}$ \\
\hline \multirow{4}{*}{$\mathrm{P}_{\max }$} & species & 4 & 28.21 & 59.8 & 231.5 & $<0.001$ \\
& season & 3 & 5.08 & 8.1 & 41.7 & $<0.001$ \\
& interaction & 12 & 2.84 & 18.1 & 23.3 & $<0.001$ \\
& error & 216 & 0.12 & 14.0 & & \\
& species & 4 & 4.24 & 26.8 & 21.1 & $<0.001$ \\
$\mathrm{R}_{\mathrm{d}}$ & season & 3 & 6.29 & 29.8 & 31.3 & $<0.001$ \\
& interaction & 12 & 1.34 & 25.4 & 6.7 & $<0.001$ \\
& error & 57 & 0.20 & 18.1 & & \\
\hline
\end{tabular}

showed a rather high photosynthetic efficiency when compared with the other shallow water species $(C$. balearica and $P$. pavonica) (Table 6).

Dark respiration showed a much stronger seasonality than $\mathrm{P}_{\max }$. The seasonal variation explained $29.8 \%$ of the total variance in the five perennial species (Table 2). Dark respiration was significantly lower for all species in winter $(\mathrm{p}<0.001)$, and there were no differences between spring and summer. Differences between species were also noteworthy and explained almost $27 \%$ of the variance (Table 2). The interaction between species and seasons was also highly significant, which means that species-specific patterns were found in dark respiration seasonality (Table 2 ). The highest dark respiration values corresponded to $D$. polypodioides and D. fasciola (Fig. 4E, Table 7).

The variance explained by the two first axes of a PCA performed using all seasonal photosynthetic parameters for the species studied was very high $(47.3 \%$ axis I, $34.3 \%$ axis II). Photosynthetic efficiency, light at saturation and light at compensation were closely associated with the first axis, while photosynthesis at saturation and dark respiration were associated with the second axis (Fig. 5). Low $\mathrm{P}_{\max }$ values are usually associated with a low dark respiration (as occurs in winter samples) and vice versa. However, neither $\mathrm{P}_{\max }$ nor $R_{d}$ show any significant relationship with $I_{c}$ and $I_{k}$, while $I_{c}$ and $I_{k}$ are closely related with each other and show a high positive relationship with light attenuation with depth $\left(I_{z}\right)$. Deep-water species show the lowest $I_{k}$ and $I_{c}$, as displayed by the inverse relationship between depth and $\mathrm{I}_{\mathrm{k}}$ and $\mathrm{I}_{\mathrm{c}}$ in Figure $5 . \mathrm{I}_{\mathrm{k}}$ and $\mathrm{P}_{\max }$ are independent, as are also $\mathrm{P}_{\max }$ and $\alpha(\mathrm{p}>0.05)$. However, the only species that shows a low $\mathrm{P}_{\max }$ and a high $\alpha$

Table 3. - Correlations between the photosynthetic parameters, dark respiration and the daily highest PFD arriving at each depth. Nonsignificant (ns), $\mathrm{p}<0.05(*), \mathrm{p}<0.001(* * *)$.

\begin{tabular}{ccccccc}
\hline & & $\mathrm{P}_{\max }$ & $\mathrm{I}_{\mathrm{k}}$ & $\mathrm{I}_{\mathrm{c}}$ & $\mathrm{a}$ & $\mathrm{R}_{\mathrm{d}}$ \\
\hline \multirow{4}{*}{$\operatorname{Ln}\left(\mathrm{I}_{\mathrm{z}}\right)$} & $\mathrm{r}$ & 0.13 & 0.66 & 0.71 & -0.47 & 0.27 \\
& $\mathrm{p}$ & $\mathrm{ns}$ & $* * *$ & $* * *$ & $*$ & $\mathrm{~ns}$ \\
& $\mathrm{n}$ & 25 & 24 & 25 & 25 & 25 \\
& $\mathrm{Ln}\left(\mathrm{I}_{\mathrm{z}}\right)$ & « depth: $\mathrm{r}=-0.91$ & $* * *$ & $\mathrm{n}=20$ & & \\
\hline
\end{tabular}


Table 4. - Light at saturation $\left(I_{k}\right.$, in $\mu$ mol photon $\left.\mathrm{m}^{-2} \mathrm{~s}^{-1}\right)$ for species and season.

\begin{tabular}{lcccccc}
\hline \multicolumn{1}{c}{$\mathrm{I}_{\mathrm{k}}$} & winter & spring & summer & autumn & mean & sd \\
\hline Carpodesmia stricta & 384.4 & 266.7 & 934.1 & 223.0 & 452.0 & 328.5 \\
Dictyota fasciola & 139.3 & 122.5 & - & - & 130.9 & 11.9 \\
Padina pavonica & - & 301.5 & 186.3 & 178.0 & 221.9 & 69.1 \\
Carpodesmia balearica & 253.4 & 242.4 & 423.5 & 295.9 & 303.8 & 83.1 \\
Dictyopteris polypodioides & 143.2 & 79.7 & 268.7 & 128.6 & 155.1 & 80.5 \\
Flabellia petiolata & 45.6 & 32.7 & 75.0 & 85.0 & 59.6 & 24.5 \\
Halopteris filicina & 70.1 & 91.4 & 116.7 & 109.2 & 96.8 & 20.8 \\
\hline
\end{tabular}

Table 5. - Light at compensation $\left(\mathrm{I}_{\mathrm{c}}\right.$, in $\mu \mathrm{mol}$ photon $\mathrm{m}^{-2} \mathrm{~s}^{-1}$ ) for species and season.

\begin{tabular}{|c|c|c|c|c|c|c|}
\hline $\mathrm{I}_{\mathrm{c}}$ & winter & spring & summer & autumn & mean & sd \\
\hline Carpodesmia stricta & 22.2 & 31.7 & 44.7 & 25.0 & 30.9 & 10.0 \\
\hline Dictyota fasciola & 8.4 & 23.7 & - & - & 16.1 & 10.8 \\
\hline Padina pavonica & - & 22.3 & 16.2 & 20.7 & 19.7 & 3.1 \\
\hline Carpodesmia balearica & 10.5 & 19.8 & 12.7 & 24.5 & 16.9 & 6.5 \\
\hline Dictyopteris polypodioides & 2.8 & 8.2 & 20.6 & 7.9 & 9.9 & 7.6 \\
\hline Flabellia petiolata & 3.2 & 3.5 & 11.7 & 11.5 & 7.5 & 4.8 \\
\hline Halopteris filicina & 2.6 & 10.2 & 14.9 & 3.8 & 7.9 & 5.7 \\
\hline
\end{tabular}

Table 6. - Photosynthetic efficiency $(\alpha)$ for species and season.

\begin{tabular}{|c|c|c|c|c|c|c|}
\hline$\alpha$ & winter & spring & summer & autumn & mean & sd \\
\hline Carpodesmia stricta & 0.02 & 0.03 & 0.01 & 0.03 & 0.02 & 0.01 \\
\hline Dictyota fasciola & 0.11 & 0.14 & - & - & 0.12 & 0.02 \\
\hline Padina pavonica & - & 0.04 & 0.07 & 0.08 & 0.06 & 0.02 \\
\hline Carpodesmia balearica & 0.07 & 0.04 & 0.03 & 0.07 & 0.05 & 0.02 \\
\hline Dictyopteris polypodioides & 0.09 & 0.15 & 0.11 & 0.23 & 0.14 & 0.06 \\
\hline Flabellia petiolata & 0.09 & 0.20 & 0.09 & 0.07 & 0.11 & 0.06 \\
\hline Halopteris filicina & 0.13 & 0.17 & 0.13 & 0.10 & 0.13 & 0.03 \\
\hline
\end{tabular}

Table 7. - Dark respiration $\left(\mathrm{R}_{\mathrm{d}}\right.$, in $\left.\mathrm{mg} \mathrm{O}_{2} \mathrm{gAFDW}^{-1} \mathrm{~h}^{-1}\right)$ for species and season.

\begin{tabular}{|c|c|c|c|c|c|c|}
\hline $\mathrm{R}_{\mathrm{d}}$ & winter & spring & summer & autumn & mean & sd \\
\hline Carpodesmia stricta & 0.53 & 0.96 & 0.75 & 0.78 & 0.76 & 0.18 \\
\hline Dictyota fasciola & 1.16 & 3.28 & - & - & 2.22 & 1.50 \\
\hline Padina pavonica & - & 1.65 & 1.55 & 2.07 & 1.76 & 0.28 \\
\hline Carpodesmia balearica & 0.35 & 1.35 & 1.76 & 0.86 & 1.08 & 0.61 \\
\hline Dictyopteris polypodioides & 0.49 & 2.11 & 3.37 & 2.08 & 2.01 & 1.18 \\
\hline Flabellia petiolata & 0.19 & 0.68 & 1.12 & 1.06 & 0.76 & 0.43 \\
\hline Halopteris filicina & 0.60 & 2.49 & 1.88 & 0.21 & 1.30 & 1.07 \\
\hline
\end{tabular}

is Flabellia petiolata, and if we delete this species from the relationship, all the other species show a low but positive relationship between $\mathrm{P}_{\max }$ and $\alpha(\mathrm{r}=0.54$, $\mathrm{p}<0.05, \mathrm{n}=21)$.

Carbon $(\mathrm{C})$, nitrogen $(\mathrm{N})$ and phosphorus $(\mathrm{P})$ content in tissue of the different species is summarized in Table 8 . P content was always lower than $0.15 \%$ of dry weight. The highest values were found in winter and the lowest in late spring and summer. $\mathrm{N}$ content ranged between $0.5 \%$ and $2 \%$ in all the species, with the exception of the only green alga, Flabellia petiolata, for which it was around $4 \%$. N content was also highest in winter and lowest in late spring. $\mathrm{C}$ content ranged from $19 \%$ to $42 \%$ and showed no clear seasonal pattern. The low summer $\mathrm{P}$ content means that $\mathrm{C}: \mathrm{P}$ and $\mathrm{N}: \mathrm{P}$ ratios increased in spring and summer in most species. $\mathrm{C}: \mathrm{N}$ ratios showed no consistent pattern except for the increase from winter to spring (Fig. 6). $\mathrm{N}$ and $\mathrm{P}$ content in tissues was correlated with depth, but $\mathrm{C}$ content was not (Table 9). Thus, $\mathrm{C}: \mathrm{N}$ and $\mathrm{C}: \mathrm{P}$ ratios were lower in the species thriving in deep waters than in those thriving in shallow waters $(\mathrm{r}=-0.73$ and $\mathrm{r}=-0.62$, respectively, $\mathrm{p}<0.001, \mathrm{n}=25)$. However, if Flabellia petiolata, which has a very high $\mathrm{N}$ content, was disregarded, correlation levels were lower (Table 9).

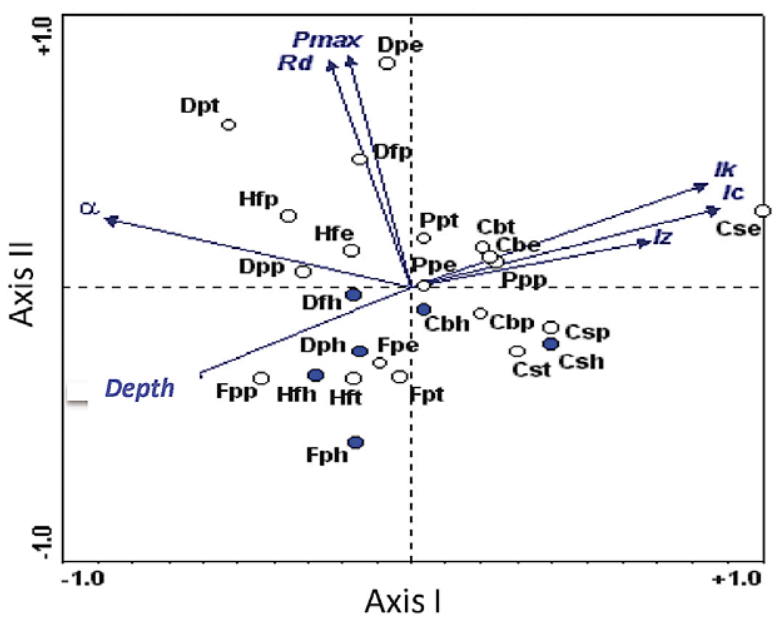

Fig. 5. - Representation of the species and seasons in a plane defined by axes I and II from a PCA made using the photosynthetic parameters as variables. Depth and $\mathrm{I}_{\mathrm{z}}$ (irradiance at every depth and season) are not variables but have been incorporated into the representation. Full dots indicate winter samples. Every species and season is indicated by the same abbreviation as that used in Figure 4 followed by season (p, spring; e, summer; t, autumn; h, winter). 

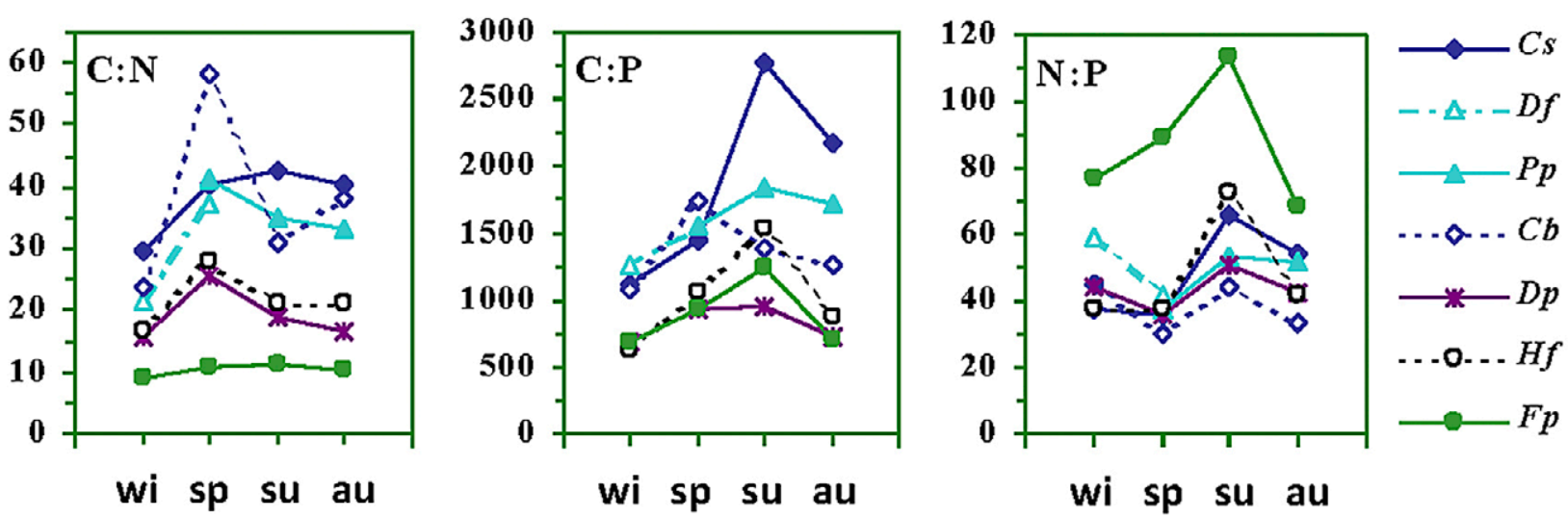

Fig. 6. - C:N, C:P and N:P ratios in tissues for each species and season. Abbreviations as in Figure 4. Cs, Carpodesmia stricta; Df, Dictyota fasciola; Pp, Padina pavonica; Cb, Carpodesmia balearica; Dp, Dictyopteris polypodioides; Fp, Flabellia petiolata; Hf, Halopteris filicina.

Table 8. - Carbon $(\% \mathrm{C})$, nitrogen $(\% \mathrm{~N})$ and phosphorus $(\% \mathrm{P})$ contents in algal tissues: seasonal values and averages (mean $\pm \mathrm{sd})$.

\begin{tabular}{|c|c|c|c|c|c|c|}
\hline$\% \mathrm{C}$ & winter & spring & summer & autumn & mean & sd \\
\hline C. stricta & 32.6 & 33.3 & 34.4 & 30.9 & 32.8 & 1.6 \\
\hline D. fasciola & 30.2 & 37.1 & - & - & 33.7 & 4.0 \\
\hline P. pavonica & - & 20.1 & 19.2 & 21.1 & 20.1 & 0.9 \\
\hline C. balearica & 30.4 & 33.6 & 36.4 & 33.3 & 33.4 & 2.3 \\
\hline D. polypodioides & 25.9 & 27.7 & 31.2 & 32.8 & 29.4 & 3.0 \\
\hline F. petiolata & 37.3 & 42.4 & 38.4 & 35.9 & 38.5 & 2.9 \\
\hline H. filicina & 25.3 & 27.7 & 28.5 & 23.7 & 26.3 & 2.1 \\
\hline$\% \mathrm{~N}$ & winter & spring & summer & autumn & mean & sd \\
\hline C. stricta & 1.29 & 0.98 & 0.95 & 0.90 & 1.03 & 0.18 \\
\hline D. fasciola & 1.65 & 1.17 & - & - & 1.41 & 0.28 \\
\hline$P$. pavonica & - & 0.57 & 0.65 & 0.75 & 0.65 & 0.09 \\
\hline C. balearica & 1.49 & 0.67 & 1.36 & 1.02 & 1.14 & 0.34 \\
\hline D. polypodioides & 1.93 & 1.26 & 1.96 & 2.29 & 1.86 & 0.41 \\
\hline$F$. petiolata & 4.85 & 4.69 & 4.10 & 4.11 & 4.44 & 0.38 \\
\hline H. filicina & 1.79 & 1.17 & 1.57 & 1.32 & 1.46 & 0.26 \\
\hline$\% \mathrm{P}$ & winter & spring & summer & autumn & mean & sd \\
\hline C. stricta & 0.076 & 0.060 & 0.032 & 0.037 & 0.05 & 0.02 \\
\hline D. fasciola & 0.062 & 0.062 & - & - & 0.06 & 0.00 \\
\hline P. pavonica & - & 0.033 & 0.027 & 0.032 & 0.03 & 0.00 \\
\hline C. balearica & 0.073 & 0.050 & 0.068 & 0.068 & 0.06 & 0.01 \\
\hline D. polypodioides & 0.097 & 0.077 & 0.084 & 0.118 & 0.09 & 0.02 \\
\hline$F$. petiolata & 0.140 & 0.116 & 0.080 & 0.134 & 0.12 & 0.02 \\
\hline H. filicina & 0.106 & 0.069 & 0.048 & 0.070 & 0.07 & 0.02 \\
\hline
\end{tabular}

Table 9. - Correlation ( $\mathrm{r}$ ) between $\mathrm{C}, \mathrm{N}$ and $\mathrm{P}$ content in algal tissues with the depth at which specimens were collected, considering all the species and (inside brackets) not including the green alga Flabellia petiolata. ns: non-significant, $* \mathrm{p}<0.05, * * * \mathrm{p}<0.001$.

\begin{tabular}{cccccccc}
\hline & \multicolumn{3}{c}{$\mathrm{C}$} & \multicolumn{2}{c}{$\mathrm{N}$} & \multicolumn{2}{c}{$\mathrm{P}$} \\
\hline \multirow{4}{*}{ depth } & $\mathrm{r}$ & 0.19 & $(0.24)$ & 0.68 & $(0.49)$ & 0.65 & $(0.48)$ \\
& $\mathrm{p}$ & $\mathrm{ns}$ & $(\mathrm{ns})$ & $* * *$ & $(*)$ & $* * *$ & $(*)$ \\
& $\mathrm{n}$ & 25 & $(21)$ & 25 & $(21)$ & 25 & $(21)$ \\
\hline
\end{tabular}

\section{DISCUSSION}

The vertical distribution of the species agrees with the patterns previously described from Cabrera (Ballesteros 1993, Sant et al. 2017) and other localities from the northwestern Mediterranean (e.g. Feldmann 1937, Verlaque 1987, Ballesteros 1992). C. stricta, $P$. pavonica, D. fasciola and C. balearica are considered photophilic species ("sun" macroalgae), while D. polypodioides, $H$. filicina and $F$. petiolata show a sciaphilic to hemisciaphilic behaviour ("shade" macroalgae) (Boudouresque 1984).
Light at compensation $\left(I_{c}\right)$ was the photosynthetic parameter that showed the best trend of change with depth. $I_{c}$ values measured here are consistent with those found in other papers (e.g. King and Schramm 1976, Gao and Umezaki 1988). In fact, low I values are considered a good indicator of the capacity of surviving in a light-limited environment (Dring 1992, Kirk 1994). Here we found that "shade" macroalgae show the lowest $\mathrm{I}_{\mathrm{c}}$ (usually $<10 \mu \mathrm{mol}$ photon $\mathrm{m}^{-2} \mathrm{~s}^{-1}$ ). Deep-water macroalgae also show a higher photosynthetic efficiency $(\alpha)$, which indicates their adaptation to capture the low light that reach the depths where they thrive. The exception here is Dictyota fasciola, whose $\alpha$ is similar to that of deep-water macroalgae. This high efficiency could be related to its short life span, since high $\alpha$ should provide a competitive advantage in its short growing period in comparison with other lowgrowing but more persistent macroalgae (in the sense of King and Schramm 1976 and Peckol and Ramus 1988). Nevertheless, the $I_{c}$ of $D$. fasciola is similar to that of other species thriving in the same environment 
( $P$. pavonica, $C$. balearica) and is much higher than that of the deep-water macroalgae studied here, reinforcing its shallow distribution range. A third parameter related to the depth distribution of macroalgae is $\mathrm{I}_{\mathrm{k}}$, which decreases with depth, as already stated (e.g. Ramus et al. 1976, Lüning 1981, Orfanidis 1992). The values obtained here are consistent with those predicted by Lüning (1981) for intertidal $\left(\mathrm{I}_{\mathrm{k}}=400-600\right)$, shallowwater $(=150-200)$ and deep-water macroalgae $(<100$ $\mu \mathrm{mol}$ photon $\left.\mathrm{m}^{-2} \mathrm{~s}^{-1}\right)$. Moreover, the species showing $\mathrm{I}_{\mathrm{k}}$ values higher than $200 \mu \mathrm{mol}$ photon $\mathrm{m}^{-2} \mathrm{~s}^{-1}$ also display $\alpha$ values lower than 0.10 in average, suggesting that macroalgae that are better adapted to thriving in low light environments attain saturation of photosynthesis at lower light levels than those thriving in a high light environment, supporting the hypothesis of the existence of "sun" and "shade" macroalgae. In short, $\mathrm{I}_{\mathrm{c}}, \mathrm{I}_{\mathrm{k}}$ and $\alpha$ show a species variation trend related to the depth where macroalgae dominate the seascape and to their light environment. In general, we can hold that these three parameters are useful to discern between photophilic and sciaphilic algae, with the only exception of the already commented high $\alpha$ of $D$. fasciola from shallow waters.

However, the results obtained at saturation irradiances $\left(\mathrm{P}_{\max }\right)$ and dark respiration $\left(\mathrm{R}_{\mathrm{d}}\right)$ are not related to seaweed distribution. For instance, although the lowest $\mathrm{P}_{\max }$ corresponds to $F$. petiolata collected at -50 $\mathrm{m}$, the highest $\mathrm{P}_{\max }$ corresponds to $D$. polypodioides at $-25 \mathrm{~m}$ and not to a shallow water alga, as predicted. These results agree with those obtained by Ramus et al. (1976) and Peckol and Ramus (1988), who also found higher $\mathrm{P}_{\max }$ values in deep-water than in shallow-water macroalgae. Gerard (1988) also observed higher $\mathrm{P}_{\max }$ values in Laminaria saccharina thriving at intermediate depths, and Gómez (1997) also concluded that $\mathrm{P}_{\text {max }}$ and depth are not related. Photosynthetic activity of algae at saturation levels seems to be more related to the shape and thickness of the thallus than to the light environment, being higher in thin than in thick thalli (Ramus 1978, Littler and Littler 1980, Johansson and Snoeijs 2002), which would explain why D. fasciola and D. membranacea show the highest $\mathrm{P}_{\max }$. On the other hand, the thinnest algae show the highest respiration rates, in agreement with observations by King and Schramm (1976), Littler (1980) and Markager and Sand-Jensen (1992), while the thickest algae (C. stricta and $C$. balearica) maintain the $\mathrm{R}_{\mathrm{d}}$ at low levels, close to the $10 \%$ of $\mathrm{P}_{\max }$.

$\mathrm{P}_{\max }$ and $\mathrm{R}_{\mathrm{d}}$ differ greatly between species and especially within seasons, as they are conditioned by temperature (Raven and Geider 1988, Davison 1991, Henley 1993). The ultraoligotrophy of the waters in Cabrera, with annual average nitrate values around $0.47 \mu \mathrm{mol} \mathrm{l}^{-1}$ and phosphate values around $0.05 \mu \mathrm{mol}$ $1^{-1}$ (Ballesteros and Zabala 1993) could also limit $\mathrm{P}_{\max }$, as it has been reported in tropical seas by Lapointe et al. (1987), Littler et al. (1988) and Littler and Littler (1992), and in temperate seas by Flores-Moya et al. (1995). In fact the phosphorous content in the tissues of the six brown algae are extremely low $(0.05 \%$ to $0.09 \%$ ), and nitrogen ranges between $1 \%$ and $1.9 \%$. $\mathrm{P}$ values are always below the critical value of 0.13 (Gerloff and Krombholz 1966), and $\mathrm{N}$ values are close to the critical values of $1.5 \%$ to $1.9 \%$ proposed by Fujita et al. (1989) and Hanisak (1979), pointing to a strong limitation of photosynthesis and growth caused by low nutrient availability. In general, deep-water algae are the richest in $\mathrm{N}$ and $\mathrm{P}$, and interspecific differences are lower in winter, in agreement with a higher nutrient availability. This is why nutrient content is usually higher in deep-water algae, which are the ones that show the highest $\mathrm{I}_{\mathrm{c}}, a$ and $\mathrm{I}_{\mathrm{k}}$. In brown algae, the highest $\mathrm{P}_{\max }$ also corresponds to the algae displaying the highest $\mathrm{N}$ and $\mathrm{P}$ content and the lowest $\mathrm{C}: \mathrm{N}$, suggesting a nutrient limitation for the algae studied here.

Our results seem to support the predictions of a lack of chronic photoinhibition in the shallow water algae studied (C. stricta, D. fasciola and $P$. pavonica). $C$. balearica, $D$. polypodioides and $H$. filicina showed a significant photoinhibitory response at irradiances higher than $800 \mu \mathrm{mol} \mathrm{m} \mathrm{m}^{-2} \mathrm{~s}^{-1}$, in agreement with their sciaphilic distribution. However, $F$. petiolata, collected at $-50 \mathrm{~m}$ showed no sign of photoinhibition even at irradiances 1000 times higher than those found in its habitat. Boudouresque (1984) defines this species as antisciaphilic, i.e. a species that is sciaphilic but also able to thrive in shallow waters at high temperature and light levels, as also reported by Drew and Larkum (1967) and Larkum et al. (1967) on the Maltese coast. Thus, we believe that $F$. petiolata is confined to deep waters, not because it cannot stand high irradiances but probably because of other factors such as hydrodynamism, competition for space or herbivory. However, its behaviour as a shade plant (high photosynthetic efficiency, low $I_{c}$ and low $I_{k}$ ) points to a very good adaptation to thriving in deep waters.

The low winter temperature seems to be responsible for the low respiration observed in all the species, in agreement with other studies (King and Schramm 1976). Seasonal variations in photosynthetic efficiency seem to be a response to seasonal changes in solar radiation. We estimated the number of hours with irradiances higher than $I_{c}$ and equal to or higher than $I_{k}$ from $I_{c}, I_{k}$, day length and light attenuation in the water column for each species (Table 10). Deep-water algae almost always have 6 hours of light higher than $I_{c}$, which means that net production occurs for at least 6 hours. Shallow water algae have between 8 and 14 hours a day, depending on the season. Saturation irradiance of shallow water algae is always lower than the days' highest irradiance, which means that photosynthesis is already saturated long before midday, and they have 6 to 12 hours of net production every day. Around the winter solstice, light could limit photosynthesis in algae found deeper than $10 \mathrm{~m}(C$. balearica, D. membranacea, $F$. petiolata i $H$. filicina), since $\mathrm{H}_{\text {sat }}$ equals 0 (Table 10). Deep-water algae only can reach $\mathrm{P}_{\max }$ at the end of spring and, in the case of $D$. polypodioides, also in summer. Thus, production seems to be limited by light for most of the year. In spring, though $F$. petiolata has a lower $\mathrm{P}_{\max }$ than $H$. filicina, it is more efficient (with a much lower $\mathrm{I}_{\mathrm{k}}$ ). This clearly benefits $F$. petiolata, because its net production is positive for 10 
Table 10. - Hours of daylight with irradiances higher than $\mathrm{I}_{c}\left(\mathrm{H}_{\text {prod }}\right)$ and equal to or higher than $\mathrm{I}_{\mathrm{k}}\left(\mathrm{H}_{\mathrm{sat}}\right)$.

\begin{tabular}{|c|c|c|c|c|c|c|}
\hline $\mathrm{H}_{\text {prod }}$ & winter & spring & summer & autumn & mean & sd \\
\hline C. stricta & 10 & 14 & 12 & 10 & 11.5 & 1.9 \\
\hline D. fasciola & 10 & 14 & - & - & 12.0 & 2.8 \\
\hline$P$. pavonica & - & 14 & 12 & 8 & 11.3 & 3.1 \\
\hline C. balearica & 10 & 14 & 12 & 8 & 11.0 & 2.6 \\
\hline D. polypodioides & 10 & 14 & 12 & 8 & 11.0 & 2.6 \\
\hline F. petiolata & 8 & 14 & 10 & 1 & 8.3 & 5.4 \\
\hline H. filicina & 10 & 12 & 10 & 6 & 9.5 & 2.5 \\
\hline $\mathrm{H}_{\mathrm{sat}}$ & winter & spring & summer & autumn & mean & $\mathrm{sd}$ \\
\hline C. stricta & 8 & 12 & 6 & 7 & 8.3 & 2.6 \\
\hline D. fasciola & 8 & 12 & - & - & 10.0 & 2.8 \\
\hline P. pavonica & - & 10 & 10 & 6 & 8.7 & 2.3 \\
\hline C. balearica & 4 & 10 & 6 & 0 & 5.0 & 4.2 \\
\hline D. polypodioides & 0 & 11 & 0 & 0 & 2.8 & 5.5 \\
\hline F. petiolata & 0 & 10 & 0 & 0 & 2.5 & 5.0 \\
\hline H. filicina & 0 & 1 & 0 & 0 & 0.3 & 0.5 \\
\hline
\end{tabular}

hours a day, while $H$. filicina requires more light and therefore has only one hour at saturation (Table 10).

In conclusion, photosynthetic responses of the studied Mediterranean algae display striking differences. Species show either "sun" and "shade" plant behaviours at low light levels, but oxygen production at high light levels and respiration seems to respond to other factors, such as thallus thickness or other environmental factors (i.e. nutrient availability). Some species (D. fasciola, D. polypodioides) show high production values in agreement with their high productivity and fast growth, while others (Carpodesmia spp.) show low production values but high biomass and durability. Thus, the rule seems to be the optimization rather than the maximization of the use of the light reaching every habitat; the species that dominates at each light level is the one that makes best use of the light environment, as suggested by Henley and Ramus (1989).

\section{REFERENCES}

Airoldi L. 2000. Effects of disturbance, life histories, and overgrowth on coexistence of algal crusts and turfs. Ecology 81: 798-814.

https://doi.org/10.1890/0012-9658(2000)081[0798:EODLHA] 2.0.CO;2

Arenas F., Fernández C., Rico J.M., et al. 1995. Growth and reproductive strategies of Sargassum muticum (Yendo) Fensholt and Cystoseira nodicaulis (Whit.) Roberts. Sci. Mar. 59: 1-8.

Arnold K.E., Murray S.N. 1980. Relationships between irradiance and photosynthesis for marine benthic green algae (Chlorophyta) of differing morphologies. J. Exp. Mar. Biol. Ecol. 43: 183-192. https://doi.org/10.1016/0022-0981(80)90025-8

Ballesteros E. 1986. Métodos de análisis estructural en comunidades naturales, en particular del fitobentos. Oecol. Aquat. 8: 117-131.

Ballesteros E. 1992. Els vegetals i la zonació litoral: espècies, comunitats i factors que influeixen en la seva distribució. Arx. Secc. Ciènc. Institut d'Estudis Catalans, Barcelona, 616 pp.

Ballesteros E. 1993. Algues bentòniques i fanerògames marines. In: Alcover J.A., Ballesteros E., Fornós J. (eds), Història Natural de l'Arxipèlag de Cabrera. CSIC-Ed. Moll, Palma de Mallorca. pp. 503-530.

Ballesteros E. 2006. Mediterranean coralligenous assemblages: a synthesis of the present knowledge. Oceanogr. Mar. Biol. Ann. Rev. 44: 123-195. https://doi.org/10.1201/9781420006391

Ballesteros E., Zabala M. 1993. El bentos: el marc físic. In: Alcover J.A., Ballesteros E., Fornós J. (eds), Història Natural de l'Arxipèlag de Cabrera. CSIC-Ed. Moll, Palma de Mallorca. pp. 663-685.

Ballesteros E., Zabala M., Uriz J.M. et al. 1993. El bentos: les comu- nitats. In: Alcover J.A., Ballesteros E., Fornós J. (eds), Història Natural de l'Arxipèlag de Cabrera. CSIC-Ed. Moll, Palma de Mallorca. pp. 687-730.

Beach K.S., Smith C.M. 1996. Ecophysiology of tropical rhodophytes. II Microscale acclimation in photosynthesis. J. Phycol. 32: $710-718$.

https://doi.org/10.1111/j.0022-3646.1996.00710.x

Boardman N.K. 1977. Comparative photosynthesis of sun and shade plants. Annu. Rev. Plant Physiol. 28: 355-377. https://doi.org/10.1146/annurev.pp.28.060177.002035

Boston H.L., Adams M.S., Madsen J.D. 1989. Photosynthetic strategies and productivity in aquatic systems. Aquat. Bot. 34: 27-57. https://doi.org/10.1016/0304-3770(89)90049-1

Boudouresque C.F. 1971. Méthodes d'étude qualitative et quantitative du benthos (en particulier du phytobenthos). Téthys 3 : 79-104.

Boudouresque C.F. 1984. Groupes écologiques d'algues marines et phytocénoses benthiques en Méditerranée nord-occidentale: une revue. Giorn. Bot. Ital. 118: 7-42.

Brinkhuis B.H. 1985. Growth patterns and rates. In: Littler M.M., Littler D.S. (eds), Handbook of Phycological Methods. Ecological Field Methods: Macroalgae. Cambridge University Press, Cambridge. pp. 461-478.

Davison I.R. 1991. Environmental effects on algal photosynthesis: temperature. J. Phycol. 27: 2-8. https://doi.org/10.1111/j.0022-3646.1991.00002.x

Delgado O., Ballesteros E., Vidal M. 1994. Seasonal variation in tissue nitrogen and phosphorus of Cystoseira mediterranea Sauvageau (Fucales, Phaeophyceae) in the Northwestern Mediterranean Sea. Bot. Mar. 37: 1-9. https://doi.org/10.1515/botm.1994.37.1.1

Delgado O., Rodríguez-Prieto C., Frigola-Gironés L. et al. 1995. Drought tolerance and light requirements of high and low sublittoral species of Mediterranean macroalgae of the genus Cystoseira C. Agardh (Fucales, Phaeophyceae). Bot. Mar. 38: 127-132. https://doi.org/10.1515/botm.1995.38.1-6.127

Dennison W.C. 1987. Effects of light on seagrass photosynthesis, growth and depth distribution. Aquat. Bot. 27: 15-26. https://doi.org/10.1016/0304-3770(87)90083-0

Drew E.A., Larkum W.D. 1967. Photosynthesis and growth of Udotea, a green alga from deep water. Underwater Association Report: $65-71$.

Dring M.J. 1986. Pigment composition and photosynthetic action spectra of sporophytes of Laminaria (Phaeophyta) grown in different light qualities and irradiances. Br. Phycol. J. 21: 199-207. https://doi.org/10.1080/00071618600650231

Dring M.J. 1992. The biology of Marine Plants. Cambridge University Press, Cambridge, 199 pp.

Feldmann J. 1937. Recherches sur la végétation marine de la Méditerranée: la côte des Albères. Rev. Algol. 10: 1-339.

Field C.B. 1988. On the role of photosynthetic responses in constraining the habitat distribution of rainforest plants. Aust. J. Plant Physiol. 15: 343-348. https://doi.org/10.1071/PP9880343

Flores-Moya A., Fernández J.A., Niell F.X. 1995. Seasonal variations of photosynthetic pigments, total $\mathrm{C}, \mathrm{N}$ and $\mathrm{P}$ content, and photosynthesis in Phyllariopsis purpurascens (Phaeophyta) from the strait of Gibraltar. J. Phycol. 31: 867-874. https://doi.org/10.1111/j.0022-3646.1995.00867.x 
Fujita R.M., Wheeler P.A., Edwards R.L. 1989. Assessment of macroalgal nitrogen limitation in a seasonal upwelling region. Mar. Ecol. Progr. Ser. 53: 293-303. https://doi.org/10.3354/meps053293

Gao K. Umezaki I. 1988. Comparative photosynthetic capacities of the leaves of upper and lower parts of Sargassum plants. Bot. Mar. 31: 231-236. https://doi.org/10.1515/botm.1988.31.3.231

Gerard V.A. 1988. Ecotypic differentiation in light-related traits of the kelp Laminaria saccharina. Mar. Biol. 97: 25-36. https://doi.org/10.1007/BF00391242

Gerloff G.C., Krombholz P.H. 1966. Tissue analysis as a measure of nutrient availability for the growth of angiosperm aquatic plants. Limnol. Oceanogr. 11: 529-537. https://doi.org/10.4319/1o.1966.11.4.0529

Gómez I. 1997. Life strategy and ecophysiology of Antarctic macroalgae. Ber. Polarforsch. 238: 1-99.

Gómez I., Wiencke C. 1997. Seasonal growth and photosynthetic performance of the Antarctic macroalga Desmarestia menziesii (Phaeophyceae) cultured under fluctuating Antarctic daylengths. Bot. Acta 110: 25-31. https://doi.org/10.1111/j.1438-8677.1997.tb00607.x

Gómez I., Wiencke C., Thomas D.N. 1996. Variations in photosynthetic characteristics of the Antarctic marine brown alga Ascoseira mirabilis Skottsberg in relation to age and size. Eur. J. Phycol. 31: 167-172. https://doi.org/10.1080/09670269600651341

Hanisak M.D. 1979. Nitrogen limitation of Codium fragile ssp. tomentosoides as determined by tissue analysis. Mar. Biol. 50: 319-332. https://doi.org/10.1007/BF00387009

Henley W.J. 1993. Measurement and interpretation of photosynthetic light-response curves in algae in the context of photoinhibition and diel changes. J. Phycol. 29: 729-739. https://doi.org/10.1111/j.0022-3646.1993.00729.x

Henley W.J., Ramus J. 1989. Photoacclimation of Ulva rotundata (Chlorophyta) under natural irradiance. Mar. Biol. 103: 261-266. https://doi.org/10.1007/BF00543356

Herbert S.K., Waaland J.R 1988. Photoinhibition of photosynthesis in a sun and a shade species of the red algal genus Porphyra. Mar. Biol. 97: 1-7. https://doi.org/10.1007/BF00391239

Johansson G., Snoeijs P. 2002. Macroalgal photosynthetic responses to light in relation to thallus morphology and depth zonation. Mar. Ecol. Progr. Ser. 244: 63-72. https://doi.org/10.3354/meps244063

Jones C.T., Craig S.E., Barnett A.B. et al. 2014. Curvature in models of the photosynthesis/irradiance response. J. Phycol. 41: 223-233.

King R.J., Schramm W. 1976. Photosynthetic rates of benthic marine algae in relation to light intensity and seasonal variations. Mar. Biol. 37: 215-222. https://doi.org/10.1007/BF00387606

Kirk J.T.O. 1994. Light and photosynthesis in aquatic ecosystems. Cambridge University Press, Cambridge, $509 \mathrm{pp}$. https://doi.org/10.1017/CBO9780511623370

Lapointe B.E., Littler M.M, Littler S.D. 1987. A comparison of nutrient-limited productivity in macroalgae from a Caribbean barrier reef and from a mangrove ecosystem. Aquat. Bot. 28: 243-255. https://doi.org/10.1016/0304-3770(87)90003-9

Larkum A.W.D., Drew E.A., Crosset R.N. 1967. The vertical distribution of attached marine algae in Malta. J. Ecol. 55: 361-371. https://doi.org/10.2307/2257881

Littler M.M. 1979. The effects of bottle volume, thallus weight, oxygen saturation levels, and water movement on apparent photosynthetic rates in marine algae. Aquat. Bot. 7: 21-34 https://doi.org/10.1016/0304-3770(79)90004-4

Littler M.M. 1980. Morphological form and photosynthetic performances of marine macroalgae: tests of a functional/form hypothesis. Bot. Mar. 23: 161-165. https://doi.org/10.1515/botm.1980.23.3.161

Littler M.M., Arnold K.E. 1980. Sources of variability in macroalgal primary productivity: sampling and interpretative problems. Aquat. Bot. 8: 141-156. https://doi.org/10.1016/0304-3770(80)90046-7

Littler M.M., Littler D.S. 1980. The evolution of thallus form and survival strategies in benthic marine macroalgae: field and laboratory tests of a functional form model. Am. Nat. 116: 25-44. https://doi.org/10.1086/283610

Littler M.M., Littler D.S. 1985. Handbook of Phycological Methods. Ecological Field Methods: Macroalgae. Cambridge University Press, Cambridge, 617 pp.

Littler M.M., Littler D.S. 1992. Photosynthesis vs. irradiance curves for six species of macroalgae from the Seychelles Islands under four levels of nutrient enrichment. Atoll Res. Bull. 374: 1-14. https://doi.org/10.5479/si.00775630.374.1

Littler M.M., Littler, D.S., Lapointe B.E. 1988. A comparison of nutrient- and light-limited photosynthesis in psammophytic versus epilithic forms of Halimeda (Caulerpales, Halimedaceae) from the Bahamas. Coral Reefs 6: 219-225. https://doi.org/10.1007/BF00302018

Lobban C.S., Harrison P.J. 1994. Seaweed Ecology and Physiology. Cambridge University Press, Cambridge, $366 \mathrm{pp}$. https://doi.org/10.1017/CBO9780511626210

Lüning K. 1981. Photobiology of seaweeds: ecophysiological aspects. Xth International Seaweed Symposium. Walter de Gruyter \& Co. Berlin. New York. pp. 35-55. https://doi.org/10.1515/9783110865271-005

Lüning K., Dring J.M. 1985. Action spectra and spectral quantum yield of photosynthesis in marine macroalgae with thin and thick thalli. Mar. Biol. 87: 119-129. https://doi.org/10.1007/BF00539419

Markager S., Sand-Jensen K. 1992. Light requirements and depth zonation of marine macroalgae. Mar. Ecol. Progr. Ser. 88: 83-92. https://doi.org/10.3354/meps088083

Mateo M.A., Sabaté S. 1993. Wet digestion of vegetal tissue using a domestic microwave oven. Anal. Chim. Acta 279: 273-279. https://doi.org/10.1016/0003-2670(93)80326-G

Orfanidis S. 1992. Light requirements for growth of six shade-acclimated Mediterranean macroalgae. Mar. Biol. 112: 511-515. https://doi.org/10.1007/BF00356298

Peckol P., Ramus J. 1988. Abundances and physiological properties of deep-water seaweeds from Carolina outer continental shelf. J. Exp. Mar. Biol. Ecol. 115: 25-39. https://doi.org/10.1016/0022-0981(88)90187-6

Ramus J. 1978. Seaweed anatomy and photosynthetic performance: the ecological significance of lightguides, heterogeneous absorption and multiple scatter. J. Phycol. 14: 352-362. https://doi.org/10.1111/j.1529-8817.1978.tb00312.x

Ramus J., Beale S.I., Mauzerall D. 1976. Correlation of changes in pigment content with photosynthetic capacity of seaweeds as a function of water depth. Mar. Biol. 37: 231-238. https://doi.org/10.1007/BF00387608

Raven J.A., Geider R.J. 1988. Temperature and algal growth. New Phytol. 110: 441-461. https://doi.org/10.1111/j.1469-8137.1988.tb00282.x

Romero J. 1981. Biomasa de comunidades de algas bentónicas de las islas Medes (Girona). Oecol. Aquat. 5: 87-93.

Sala E., Ballesteros E. 1997. Partitioning of space and food resources by three fish of the genus Diplodus (Sparidae) in a Mediterranean rocky infralittoral ecosystem. Mar. Ecol. Progr. Ser. 152: 273-283. https://doi.org/10.3354/meps 152273

Sant N., Chappuis E., Rodríguez-Prieto C. et al. 2017. Cost-benefit of three different methods to study Mediterranean rocky assemblages. Sci. Mar. 81: 129-138. https://doi.org/10.3989/scimar.04463.04A

Spence D.H.N. 1976. Light and plant response in freshwater. In: Evans G.C., Bainbridge R., Rackham O. (eds), Light as an ecological factor. Blackwell, Oxford. pp. 93-133.

Teixidó N., Gambi M.C., Parravacini V. et al. 2018. Functional diversity loss along natural $\mathrm{CO}_{2}$ gradients. Nat. Commun. 9: 5149 . https://doi.org/10.1038/s41467-018-07592-1

Ter Braak C.J.F. 1990. Update notes: CANOCO version 3.1. Agricultural Mathematics Group, Wageningen, $35 \mathrm{pp}$.

Tomas F., Cebrian E., Ballesteros E. 2011. Differential herbivory of invasive algae by native fish: temporal and spatial variability. Estuar. Coast. Shelf Sci. 92: 27-34. https://doi.org/10.1016/j.ecss.2010.12.004

Verlaque M. 1987. Contribution à l'étude du phytobenthos d'un ecosystème photophile termophile en Méditerranée Occidentale. PhD Thesis, Univ. d'Aix-Marseille. 389 pp. 